\title{
Revolutionary Songs as a strategy of Transforming Listeners' Mindset: The Zimbabwean Practice after 1999.
}

Mediel Hove*, Tawnda Mukurunge ${ }^{\dagger}$

\begin{abstract}
In a country whose history of the struggle for liberation dates back close to a century from 1890 to 1980, it is apparent that the milieu is dominated by anti-imperialist sentiments. This study outlines media theories and their relevance to Zimbabwe. In addition, it assesses the impact of the Zimbabwe Broadcasting Holdings' [ZBH] policy of playing one revolutionary song out of every five songs played on air, as a means of sensitizing listeners into supporting the Zimbabwe African National Union Patriotic Front [ZANU-PF]. Hinging on quantitative and qualitative methods the study argues that the policy of playing one revolutionary song out of every five songs, did not necessarily affect the listeners in the manner they were meant to be influenced. A significant number of the Listeners' tastes and mindsets up to date have not been reoriented as the ZBH and the policy making brains behind the scenes had intended. In fact, using radio broadcast to try and manipulate the way people think towards a particular political party's ideology received limited support. It concludes that the majority of radio listeners in Zimbabwe today are no longer interested in the mantra of perpetual liberation war rhetoric.
\end{abstract}

Keywords: Media theories, Africa, Southern Africa, Zimbabwe Broadcasting Holdings, policy, revolutionary song, listeners, mindset.

\footnotetext{
* A doctoral student in the Peace-building Programme at Durban University of Technology and Lecturer in the History Department, University of Zimbabwe P. O Box MP 167, Mount Pleasant, Harare Zimbabwe, medielhove@yahoo.co.uk, Continent: Africa.

$\dagger$ Tawnda Mukurunge: Director of Journalism, Christian College of Southern Africa, P. O. Box 3488, Harare, Zimbabwe, tawandamukurunge@hotmail.com. Continent: Africa.
} 


\section{Introduction}

Zimbabwe was under colonial rule for a very long period from 1890 to 1980 and it was this lengthy time of subjugation which compelled the affected Black people to resort to an anti-imperialist struggle. Black majority rule was achieved in 1980, an effective thirty-three years before this study was carried out. In the post independence period the struggle hinged on ideological incompatibilities between a Black government that has been in power since 1980 and the west which accused the black led government of corruption, bad governance, human rights violations and mismanagement of the economy. The presentation asserts that the government controlled the Zimbabwe Broadcasting Holdings (ZBH) trying to buttress and publicize ZANU-PF ideologically. It sought to establish the extent to which the ZBH succeeded in its mandate of ensuring that in every five songs played on air by National FM one had to be a revolutionary song. It did this by investigating the effectiveness of National FM's efforts in fulfilling the proposed policy. It examined the responses by listeners to the imposition of revolutionary songs by the Radio Stations and the extent to which musical genre in a political volatile environment assumes an ideological thrust. To collect data the study used structured questionnaires which were distributed to National FM fan club members, producers and presenters in an effort to establish the impact of revolutionary music. To corroborate the views of the presenters, key informant interviews were carried out with specialists in media issues. In fact, it concludes, that using radio broadcast to try and manipulate the way people think towards a particular political party's ideology received limited support and that the majority of radio listeners in Zimbabwe today are no longer interested in the mantra of perpetual liberation war rhetoric.

\section{Objectives of study}

This study sought to;

- Establish the relevance of media theories in independent Zimbabwe.

- Investigate how constant playing of revolutionary music to National FM listeners influenced their thinking and their political orientation.

- Examine how ideology influenced the constant playing of revolutionary music.

- Evaluate the Zimbabwe Broadcasting Holdings (ZBH) overall policy on music.

\section{A Reflection into the Relevance of the Media Theories}

There are several media theories and some of these are discussed below especially those that have influenced the development of media in Zimbabwe.

\section{Ideology and Hegemony}

Ideology and Hegemony are relative concepts that attempt, among other things, to explain how the social processes of interpretation of everyday human activity and communication are entrenched in power relationships. The two concepts conjecture that those in authority, the ruling elite, impose their global-view on the moderately defenseless through the establishment of meanings in everyday 
communication. Hegemony, however, goes further to suggests that the moderately powerful ensure the continuous domination of their world-view by subtly incorporating any oppositional global-view into their dominant view. This section seeks to find out the media theories that influenced the media in post independence Zimbabwe.

Normative press theories refer to the concepts that underline the ideal role of what the media is expected to be rather than what necessarily happens in practice. ${ }^{1}$ Press theories explain issues of ideology in the way the media represent issues. They also illustrate how ownership influences news coverage. With regards to press theories each society attempts to define the role of the media, in spite of the fact that the media, in most cases is from the beginning a business venture that thrives to meet the expectations of the owner. Fundamental to normative theory is media behaviour or coverage of issues in relation to the state, and the expectations of the state of the role of the media. This study exposes the ideal role especially what the media is expected to be rather than what necessarily happens in practice.

\title{
Authoritarian Press Theory
}

Authoritarian Press Theory refers to the state in which media freedoms are non-existent. ${ }^{2}$ The media are used by those in power for the furtherance of the ideology of the ruling class. Referring to the authoritarian theory, Rivers and Schramm (1969) write:

\begin{abstract}
Modern communication was born in 1450 into an authoritarian society. The essential characteristic of an authoritarian society is that the state ranks higher than the individual in the scale of social values. Only through subordinating himself to the state can the individual achieve his goals and develop his attributes as a civilized man. As an individual, he can do little; as a member of an organized society, his potential is enormously increased. This means not only that the state ranks higher than the individual, but also that the state has a caretaker function and the individual a dependent status. The press or media located and controlled by the powers that be (office of the king or the sovereign or the Pope and, in some situations, to private persons who supported and were preferred by royalty). Overall, the media was subordinated to the state. ${ }^{3}$
\end{abstract}

Media ownership in Zimbabwe is not exclusively a state preserve since private enterprise is permitted as long as content is not against the status quo. Admittedly, there are features which resemble state media dominance, such as the Broadcasting Services Act (BSA) of 2001 and regulations such as the Access to Information and Protection of Privacy Act (AIPPA) of 2002, but these do not make the Zimbabwean media wholly authoritarian or state centric. Accordingly, in the period between 1999 and 2008 the media in Zimbabwe involved surveillance, threats, imprisonment, censorship, black mail, abuse of power and denial of justice meant to ensure control over news. The opposition news was rarely covered and until July 2009 only The Post, a Zambian newspaper was allowed to circulate in the country. Consequently the violations of media freedom and freedom of expression grew eleven fold and the private media was declared as "weapons of mass deception" and its views dubbed "weapons of mass destruction." 4 The reality is that media laws and practice in Zimbabwe are liberal. ${ }^{5}$ For example, both state and private interests own media particularly print press, despite the fact that their operations are punctuated with arrests and threats of editors and journalists. Practical examples are; The Zimbabwe Independent, News Day and The Standard on Sunday are owned by Alpha [Pvt] Ltd and The Daily News is owned by Associated Newspapers of Zimbabwe [ANZ] which are private companies. On the other hand; The Herald, H and B-Metro, The Manica Post, The Chronicle and The 
Sunday Mail and The Sunday News are owned by the public where the government controls how they operate and what they should publish and in what details.

\section{The Libertarian Press Theory}

McQuail refers to the Libertarian Press Theory as the free press theory which argues that free and public expression is the best way to arrive at the truth and expose errors. ${ }^{6}$ He further probes the principles of this theory in practice with special attention on; whose freedom the media protect, the close identification of principles of freedom with profit and private ownership and monopoly tendencies. ${ }^{7}$ The tenets of this theory are enshrined in the First Amendment of the American Constitution. ${ }^{8}$ The theory is relevant to Zimbabwe given the private ownership of some media which creates plurality in reportage and news coverage as well as consequent protection of private property interests. Just like in every other polity, there are laws that might seem to impinge on free practice of the media which include some sections of the Public Order and Securities Act [POSA] and Access to Information and Protection of Privacy Act [AIPPA]. The private press assumes the role of the watchdog of the government by being critical of some government policies. On the other hand, through various public owned media companies, such as Zimpapers and ZBH, owned by the state, the government exercises monopoly of the media.

The Social Responsibility Theory upholds the principle of freedom of the media as long as it is harnessed with responsibility. ${ }^{9}$ In addition, the theory notes that independence is desirable only as long as it is reconcilable with an obligation to society. In this sense, the media are perceived as fulfilling a role of public stewardship. They are the watchdogs on behalf of the poor and defenseless common good against government or private abuse of power or corruption. There is an emphasis on neutrality and balance, above all, a belief in media accountability to society. It may be summarized as follows:

...the power and near monopoly position of the media impose on them an obligation to be socially responsible, to see that all sides are fairly presented and that the public has enough information to decide; and that if the media do not take on themselves such responsibility, it may be necessary for some other agency of the public to enforce it. ${ }^{10}$

In Zimbabwe, the grave reportage of private media, predominantly on government projects, is centred on the tenets of the media as a watchdog of the state. On the other hand the state restricted media believe that they have to report conscientiously by covering the positive aspects achieved through the government driven projects. There are challenges on who should determine neutrality and balance of reporting, which in the case of Zimbabwe saw government closing the Daily News for exposing the government unprofessional conduct of business.

\section{Socialist-Marxist Media Theory}

The Socialist-Marxist Media theory emerged as a result of the propositions of Marx, Engels and Lenin and it is sometimes called the Soviet Media Theory. The basis of this theory is that the media serve the interests of the socialist state because the state is an embodiment of all the members of a classless society. ${ }^{11}$ It further notes that the media belong to the people and the role of the media is to socialize or sensitize people into a socialist way of life. In fact the media are a tool to inform, educate 
and mobilize people in the aims of a socialist society. In the case of Zimbabwe the theory was relevant in explaining the ZANU-PF's Socialist-Marxist ideology that saw the government investing and taking over media in order to mobilize people into a Marxist style society soon after independence in 1980. However, due to continued private ownership of media and property in the country one can conclude that the principles of this theory were not implemented in totality in Zimbabwe. Even several years after the collapse of communism in 1991, what Jonathan Moyo undertook to attain with his $75 \%$ local content seems largely to have been an attempt to forcefully indoctrinate the Zimbabwean community in what he and ZANU P F thought was good for the people to consume.

\section{The Development Media Theory}

The Development Media Theory is also known as development journalism. This theory asserts that the history of the South is different from the North due to the impact of colonialism and the diverse ethnicity of the population. ${ }^{12}$ This led to fears among Third World leaders, predominantly in Africa, and Yoweri Museveni of Uganda noted that negative reporting may fuel ethnic tensions which were made prominent by the divide and rule tactic of the colonial system. This could be one of the reasons why McQuail (1987) argues that the South needs development news instead of the Western type of news bent on condemning governments. ${ }^{13}$ The theory therefore encourages positive reporting of local issues and avoids negative publicity. The argument being that the people of the South are often struggling to survive and reporting of disasters and failures or setbacks can considerably injure the process of nation building. Zimbabwe's media in the 1980s was largely occupied with positive reportage on development at the expanse of the government's operations in Matebeleland and some parts of the Midlands provinces which led to the death of over 20000 people. $^{14}$

This was deliberately done because of the need to portray the then newly independent Zimbabwe as a peaceful country and hence promote unity and nation building. This is in theory divergent to the role of the press in Western media that is, not only meant to enlighten people, but also to scrutinize the government and its policies. ${ }^{15}$ The proponents of development Journalism argue that the strong impact of mass media and its potential to promote beneficial transformation should be harnessed to cultivate harmony, peace and nation building. Indeed peace would prevail if this was to be practiced in Zimbabwe and other conflict affected countries. Other proponents of developmental journalism have even gone further to prescribe the 'development' issues to be given coverage. Magaga Alot advocates that Africans in Kenya need simple information about agriculture, appropriate maintenance of their homesteads, and looking after their families, which would enable them to easily relate with their immediate milieu. ${ }^{16}$ On the contrary such development Journalism eliminates any critical coverage of government. The development media theory argument has also been attacked for reducing the mass media in Africa and other developing countries to a utilitarian cause and effect role. This is not dissimilar from the responsibility played by the mass media during the colonial period when African languages were used to transmit what were also called 'developmental issues' such as those singled out by Magaga Alot. The colonial administrations had a chauvinistic notion that Africans were an excited lot and therefore were not bothered about administrative issues. That is the reason why development journalism has been viewed as a conspiracy by a group of the ruling class/elites who want to suffocate political debate because they feel their country cannot accord such debates. It should be noted that the theory of developmental journalism applies precisely to the thrust of democratization and development in Zimbabwe which the government does not want to be given prominence. 


\section{Agenda Setting}

In 1963 Bernard Cohen discussed the basis of the agenda setting theory. Cohen observed that the press may not be successful much of the time in telling people what to think but is stunningly successful in telling people what to think about. ${ }^{17}$ The observation is an affirmation that the consumers of media products are not defenseless and malleable or even gullible as envisaged by the mass society theories. One of these theories, the hypodermic needle or syringe theory or the magic bullet theory portrayed the mass media as comprising, corrupting influence on 'average' consumers and as a result undermining the social order. ${ }^{18}$ A deeper scrutiny shows that the media has limited effects on consumers of media products as they cannot manage the information flow or tide quite well. Put differently, agenda setting theory posits that the mass media and not the public concerns of the consumers determine what can be topical news to be discussed and contemplated or thought about by the public. ${ }^{19}$

In other words "media agenda setting is the process whereby the news media lead the public in assigning relative importance to various public issues." ${ }^{20}$ In the case of Zimbabwe the state owned media was largely concerned about political issues neglecting the failure by the state to provide the basic human rights such as the right to education, health, freedom and food just to mention but a few. If people pay attention and absorb everything, they risk what Graber called information overload. More-so Leon Festinger (1957) using his theory of cognitive dissonance borrowed from social psychology points out that consumers also process information by patronizing it, selecting aspects of interest to them and integrating the selected information with their own thinking. ${ }^{21}$ Moreover, he argues that dissonance or mental discomfort is psychologically uncomfortable and would motivate an individual to try to reduce it in an effort to achieve consonance. In addition, to the attempt to reduce it, the individual would actively try to avoid such situations and information which would likely increase dissonance. Dissonance is reduced by three interrelated selective processes. The first process is selective exposure or attention in which consumers of media products expose themselves or attend to messages consistent with their pre-existing attitudes and beliefs. ${ }^{22}$ Furthermore, consumers use selective perception which is based on the assumption that people will interpret messages in a manner that is consistent with their pre-existing attitudes and beliefs. ${ }^{23}$ These selective processes in the theory of cognitive dissonance are seen as limiting media impact as content is selectively filtered to produce as little attitude change as possible. Given this reality on the ground it means that efforts by the Zimbabwean government to use media as a strategy of indoctrinating the people towards ZANU-PF ideology was received and interpreted differently with dissimilar results. That is to say where listeners were expected to be pro-ZANU-PF, they reacted instead against it. This was evident in the declining popularity of the party revealed in the election results tabled between 2000 and 2008.

Another way consumers are believed to 'tame' the information tide is through their active use of the media for their own needs called the uses and gratifications approach. The theory affirms that the influence of the media is limited to what people allow it to be. The consumers therefore use the media for their specific consumption. ${ }^{24}$ It applies to the highly literate and analytical Zimbabweans since a significant number believe that what is broadcast on state radio or television and what is carried by state dominated print media is correct.

Proponents of the 'new audience research,' David Morley and Charlotte Brunsdon (1978) have also shown how consumers tame the information tide. ${ }^{25}$ Using their analysis wit regards to Zimbabwe, most people who were frustrated by what was broadcast by the government dominated media houses turned to satellites and connected to different channels such as BTV, Press TV, France 24, CNN, and BBC among others. At the height of the conflict in Zimbabwe, supporters of ZANU-PF launched operation Dzikisai Madhishi (Operation Remove satellite systems). The above theories fall under the limited theories paradigm which argues that mass media are not all powerful and the 
consumers are not powerless victims as mass society theory would like to portray. Rather, they portray active consumers interacting with mass media. This is true of the Zimbabwean environment where people have turned to other sources for news such as the internet such as Face Book and satellite systems in order to be connected to different channels in search of various opinions.

It is also worth examining what makes the agenda setting theorists think that the press or media have such a potent ability to select issues which consumers assume to be topical and worthy their attention. The agenda setting hypothesis belongs to a minimal effects paradigm and it developed as a response to the above limited effects paradigm. It also developed out of the new studies of cognitive psychology that opposed the mainstream behavioral psychology. Proponents of behaviorism such as Skinner (1953) emphasized reinforcement, reward and punishment, and conditioning in shaping behaviour and even in explaining human thought and language. ${ }^{26}$ However, cognitive psychology regarded people as 'problem solvers' instead of objects of manipulation. The agenda setting is therefore related to cognitive psychology it investigates the salience or primacy that people assign to certain issues and how such primacy is arrived at. As problem solvers Zimbabweans have responded by initiating other strategies of passing on valuable information from one person to the other in face of government persecution at the height of the Zimbabwean conflict. Some of these strategies include the non verbal cues of communication, whistling and reading of newspapers which were criminalized at secluded places. To interact with their distant relatives, comrades and friends; faxes, mobile phones and different mediums of the internet were employed as a signal that ZANU-PF was wasting its time and resources in a technologically dynamic world. In early 2013, the ZANU P F supporters were confronted by a social network nicknamed Baba Jukwa on Face Book wall which revealed all the violations of the electoral process, threats to lives of targeted individuals, corruption, and disunity within the party including how the Kasukuweres all wanted to be Members of Parliament. Even its attempt to centralise the electronic system was to no avail in light of the digitalised electronic devices which escaped from the rigid surveillance strategies.

The central axiom of agenda setting is salience transfer, or the ability of the mass media to transfer what they consider as important issues on their agenda to public agenda. Media agenda is the set of issues addressed by media sources and the public agenda is the set of issues the consumers consider important. ${ }^{27}$ There are various factors that influence the effects of agenda setting on consumers of media products. The first factor is what Harold Gene Zucker calls the obtrusiveness or unobtrusiveness of the issue. Obtrusive issues are those that have direct impact on the public such as high prices of commodities in local shops. ${ }^{28}$ Unobtrusive issues are those that may not be directly experienced by the public such as global warming and pollution. In addition, Miller concludes that the effects should be much stronger for unobtrusive issues such as the public reliance on the media for information. ${ }^{29}$ More so, the agenda setting and the two-step-flow theory of information may combine in having an effect on consumers. This is because the non-users of information rely on users and both should experience the same effects. ${ }^{30}$ Both agenda setting and the two-step flow theories belong to the minimal effects paradigm. In this connection, Walgrave1 and Van Aelst stress that the subject of class or socio-economic status for political issues is in the obtrusive or unobtrusiveness of issues. ${ }^{31}$ The middle class and intellectuals are affected by unobtrusive political issues in the media more than the lower classes. More so, another dimension was identified called talkers and non talkers for those who discuss political issues. Talkers are affected by non-obtrusive issues in the print media as well as on television where as non-talkers are affected by television but not print.. Following the rise of the Movement for Democratic Change (MDC) in 1999, a significant number of Zimbabweans were free to comment on political issues both on the print and electronic media, but changed to what we would want to coin the read and view silently strategy in an effort to escape from the state motivated witchhunt tactics on those who revealed their opposed opinions.

The time lag is another factor that affects agenda setting and Winter and Ayal (1980) called it the optimal effect span. This is the pre-requisite period which lapses for an issue to be transferred 
from the media agenda to the public agenda. Furthermore, Lang and Lang (1983) illustrated agenda setting as a process by adding or incorporating the concept of agenda building that has six steps. ${ }^{32}$ These include a period where; the press highlights the issue through a headline or front page coverage, the issue gets the necessary publicity by constant repetitions, the issue gets framing or is given the desired angle for it to be topical and the choice of discourse is carefully made to affect perception. For example if a corrupt politician is identified in the much publicised agricultural inputs abuse in different parts of Zimbabwe between 2005 and 2008, at first he has been cheating on the expectant beneficiary farmers, then the discourse transforms into scam over the distribution of farming inputs and changes its tempo until the politician resigns.

The media in the fifth stage establishes connections with other general issues for people to be opinionated; for the politician the public would be anxious to gain knowledge of his religious denomination or religious organisation, his political party and comrades in arms. In the sixth stage, critics are employed as basis of assumptions to demonstrate media neutrality in the case, and give credibility through the judgment of a specialist. The seventh stage is about media salience conveyance. ${ }^{33}$ The recipients are credibly influenced by a story covered by both print and electronic media where others obtained it through; hearsay, reading and direct observation as the story unfurls. The stages reveal that agenda setting is a snowballing process.

One major setback of agenda setting theory is that it lacks a vivid impact on recipients who are already opinionated. After all, either electronic or print media has challenges in establishing distraction limitations and at the same time hide real challenges perpetually. The impact can simply modify consciousness, precedence and significance attached to given issues popularised by the media.

\section{Gate Keeping}

Gate keeping was coined by Kurt Lewin in 1947 to describe the process in which news is transmitted via a succession of confirmation points or gates prior to reaching the consumer. ${ }^{34}$ In Zimbabwe's print and the electronic media, for example, before an issue lands in the medium of transmission such as a newspaper or television, the first gate keeper is the journalist who makes a decision on credibility of the issue for the consumers' attention. If the correspondent comes up with an article it moves on to the sub-editor and then to the editor prior to its publication. In the Zimbabwean media, gate keeping is important to both state monitored and private media which scrutinises what is covered and what is excluded. Norton Long (1958) noted that before the agenda theory was advanced, the press was at the forefront of setting the territorial agenda. ${ }^{35}$ More so, Long asserted that the press has a significant part in determining what a significant number of people discuss, what they think ideas are, and answers they provide to challenges.

\section{Priming}

Another procedure of agenda setting is priming. This is the process in which the media attend to some issues and not others by giving them more attention. By so doing the media transform the standards by which people view and perceive the issue or objects or characters. ${ }^{36}$ Priming also includes how

media content is allocated time and space. By so doing the issues are made more accessible and vivid in the mind of consumers. ${ }^{37}$ Some issues may be selected as headlines, or placed on the front page. Stories may also be accompanied by photographs or visuals such as cartoons. Such cues can be repeated over time as a way to influence consumers what to think about due to frequent coverage. 
This relates aptly with ZBH's National FM's policy of playing one revolutionary song to every five songs played on air.

\section{Framing}

Thirdly, agenda setting involves the procedure of framing. This is the process of selective control over media content so as to influence public interpretation of issues. A frame in social theory consists of a schema of interpretation- that is a collection of anecdotes and stereotypes that an individual depends on to understand and respond to individuals. Framing is an extension of agenda setting. They used the term second level agenda setting to describe the impact of the important characteristics of media coverage on audiences' integration of the news stories. ${ }^{38}$ This is accomplished by emphasis, exclusion and elaboration as well as selection. Through framing, media influence how the consumers should view the issue. Framing appeals to the cognitive and affective attributes of the consumers.

\section{Ideology and Hegemony}

Ideology and hegemony are relative concepts that attempt to among other things, explain how the social processes of interpretation of everyday human activity and communication are entrenched in power relationships. The two concepts note that those in power, the ruling class, impose their worldview on the relatively powerless through creation of meanings in everyday communication. ${ }^{39}$ Hegemony, however, goes further to propose that the relatively powerful ensure the perpetual domination of their worldview by subtly incorporating any oppositional worldview into their dominant view. The political and practical implications of Gramsci's ideas were far-reaching because he warned of the limited possibilities of direct revolutionary struggle for control of the means of production; this 'war of attack' could only succeed with a prior 'war of position' in the form of struggle over ideas and beliefs, to create a new hegemony. ${ }^{40}$ To further illustrate the role of the two concepts, Karl Marx observed that; the ideas of the ruling class are in every era and situation the ruling ideas, that is, the class which is the ruling material force of society is at the same time its ruling intellectual force. The class which has the means of material production at its disposal has control at the same time over the mental production, so that generally speaking, the ideas of those who lack the means of mental production are subject to it. The ruling ideas are nothing more than the ideal expression of the dominant material relationships grasped. ${ }^{41}$

The domination of the world by the ruling class therefore, ensures their stay in power and the continual exploitation of the ordinary people. The domination is manifested in everyday communication that legitimizes the status quo. Language and other cultural products become subtle weapons of perpetual domination, and both the mass media and interpersonal communication, the vehicles to carry this dominance from the dominant group to the dominated. Such attempts were evident in the manner in which the media portrayed ZANU-PF over the years over the radio, television and the government controlled newspapers that the objective was to belittle opposition political parties and keep one party dominant.

Ideology can be defined in three closely related ways that can help in identifying the role of the concept of ideology in the creation of everyday communication. First Williams (1977) defines ideology as a system of beliefs characteristic of a social class. This explains ideology as a product of interaction of a particular social class in a given class society. For the beliefs of one class to be 'acceptable' to other groups or classes in the same society, that class should have the means to spread its ideas in addition to its relative position and power in comparison with other classes. This brings in 
the role of the media in disseminating the beliefs of the class that owns the media and the means to propagate their beliefs. Subsequently, these beliefs become widespread and Ideology and hegemony play a significant role in the creation of meanings in everyday communication.

Ideology refers to an organized belief system and set of values that is reinforced or disseminated by communication. ${ }^{42}$ Meanings and messages in the media are therefore about some beliefs rather than others depending on the dominant ideology of the organization producing the media texts. According to Gramsci (1971), hegemony is the invisible exercise of power by elite groups in a society over the rest of that society. According to Raymond Williams, in Stevenson (1995), hegemony is a continuous historical process that is always shifting and never static and systematic in its formation. ${ }^{43}$ The elite group becomes hegemonic when it transcends economic concerns and provides the people with moral and intellectual leadership. Unlike ideology, hegemony operates in a subtle and invisible manner. Hegemony and ideology are present in the beliefs and values that are kept in circulation in the media acceptable in everyday communication through interpersonal communication. ${ }^{44}$ After independence in Zimbabwe the state exercised monopoly of the media largely for the furtherance of ideology.

According to Althusser the media is an ideological state apparatus (ISA) meant to ensure the domination of the ruling class. ${ }^{45}$ Marxist theorists postulate that the class which has the means of material production at its disposal has control at the same time over the means of mental production. ${ }^{46}$ It therefore implies that that the ideas and beliefs of the powerful are the ones that are disseminated through various media texts. Those whose ideas are circulated include media owners, advertisers and the establishment.

Media organizations comply with a number of frames of references for their interpretation of events for publication or broadcasting. A frame is a central organizing idea for news content that supplies a context and suggests what the issue is through the use of selection, emphasis, exclusion and elaboration. ${ }^{47}$ The main frame is the use of ideology in order to establish, maintain, negotiate and renegotiate hegemonic tendencies.

The media disseminates dominant sets of values into society in order to create a 'consensus' on how society ought to be run. An analysis of the coverage of the current economic crisis in Zimbabwe by private and public media is an example of how ideology operates in the creation of meaning in the media. Both sections of the media covered the same economic situation but came out with different interpretations regarding the causes of the crisis as well as possible solutions to the crisis. While public media blamed sanctions imposed on the country by the west and its allies, private media blamed the ruling party and several top government officials of corrupt practices which ruined the economy.

Contents of the media and meanings carried by their messages are determined by the economic base of the media organizations. Media owners will only keep in circulation ideas which will ensure their economic survival. In both the private and public media, information that is disseminated is always in line with the editorial policy dictated by the owners or major shareholders. A befitting example came into being in Zimbabwe when the Daily News was established and began to rival the state controlled, The Herald in reporting political activities and the violation of human rights and the ZANU-PF influenced the closer of the paper thereby violating media freedom. Advertisers also determine the meanings that are kept in circulation through media. Media organizations keep in circulation messages that do not go against the beliefs and values of advertisers as they depend on revenue generated from advertising more than that generated from licensing. Consequently, the elite are able to saturate society with their preferred ideological agenda because they control the institutions that dispense symbolic forms of communication. ${ }^{48}$ The government of the day also tries to influence society through the media. Since ideology is the way in which power and communication 
interact to sustain relations of domination ${ }^{49}$ the dominant classes attempt to create social cohesion by influencing the media to reproduce social relations of inequality.

Ideology and hegemony influence the media's selective emphasis of certain values and norms, which those in power choose to, communicate. Through agenda setting, the media gives prominence to issues that it chooses in order to achieve certain purposes. Ideological sets of information are elevated and amplified by the mass media, given great legitimacy and distributed persuasively and often glamorously. In August 2008, for instance, public print and electronic media in Zimbabwe focused attention on the inter-party talks then taking place between ZANU [PF] and the MDC formations thus making them topical on the media agenda. This is in sharp contrast to the public agenda, which is most likely to be prioritized on its agenda, issues like empty shops, shortage of cash, the non-release of the 2007 high school public examination results and the dollarization of the economy among other issues. Ideology is not only found in news bulletins where information is selected and packaged but is also present in films, movies and other entertainment programmes as well.

\section{Methodological Considerations}

The study benefited immensely from quantitative and qualitative research methodology. It employed structured questionnaires that required closed and open ended responses as a data collecting method. This was followed by the researchers' meticulous analysis of Chimurenga music log sheets at the production department at National FM. More so members of the National FM Fan Club, producers and presenters at the radio station were interviewed on one on one basis.

The study used qualitative and quantitative methods although much emphasis was placed on the qualitative method. Qualitative research refers to research that is descriptive in nature and goes beyond the collected data or statistics in its analysis. The researchers chose qualitative method in a drive to arrive at the root or core of the matter. Qualitative research methodology therefore presented an opportunity to the researchers to interact with the National FM fans and collect data on their opinions about the topic understudy. These opinions assisted the researchers to establish the extent to which the policy was successful or unsuccessful in pushing the ideological agenda which was being pursued by the ZBH policy makers. On this note, qualitative research had more depth than mere gathering of statistical data, which is more characteristic of quantitative research methodology. The choice of research methodology was done by the researchers cognisant of the sensitivity of the topic, as well as of the bias that was bound to emanate from the respondents depending on their political affiliation.

Quantitative methods were used for data validation and to collect administrative information. For example, in this study a questionnaire collected quantitative data on; educational backgrounds or types of music preferred, to improve quality of service to the National FM listeners' Club Members.

\section{Data Collection}

The questionnaire was disbursed to National FM listeners through four producer/presenters at National FM, two male and two female. This was done because each of the producer/presenter had their own enthusiastic fans apart from them being overall National FM fans. Each producer/presenter was given a batch of ten questionnaires. The other ten questionnaires were disbursed through a lady who teaches in Chitungwiza who is a National FM fan. She had a wide outreach as she socialized with the parents of her primary school pupils and she also interacted with fellow members of the 
congregation at her church. She had a well knitted network. The producer/presenters had a wide outreach because one lived in Glen View while the other one stayed in the Avenues area of Harare. Harare represented urban fans and Epworth provided the fans with a semi-rural as well as farming background type of listeners.

The content of the questionnaires or the type of answers were broken down into categories to provide information on listeners' age, educational background, type of music preferred, why and how the listeners were affected by the systematic playing of revolutionary music. The researchers went to the production unit at National FM to collect data on the playing of Chimurenga music. We paid attention on the Chimurenga Music Log Sheet, where every producer/presenter recorded on daily basis every Chimurenga song played during each shift. Key informant oral interviews were also conducted with two producer/ presenters with National FM. The questions asked include the following:

- Can you briefly explain the ZBH policy with regards to playing songs on air?

- Are you aware of the ZBH policy that stipulates that for every five songs played on air, one must be a revolutionary song?

- Has this policy been enforced?

- What measures were taken against any producer/ presenter who did not adhere to this policy?

- How have your fans been reacting to this policy?

- As a producer/ presenter who knows his/ her fans' musical tastes, what are your views on this policy?

\section{Findings Presented}

Of the fifty questionnaires that were disbursed, thirty six were returned. Of these thirty six questionnaires, twenty seven respondents were females aged between thirty six and forty-five. Of these twenty-seven females, fourteen were housewives and thirteen are employed in both public service and the private sector. In terms of educational qualifications of the fourteen housewives, six went beyond ordinary level. All the female respondents have been listeners of National FM (or Radio 4) for more than five years.

The favorite programmes by the twenty seven female respondents were; morning shows which had ten respondents citing it as their favorite followed by lunchtime listening which had seven, developmental programmes had five, drive time listening had three and culture programmes had two. These findings are given in figure 1 . 
Figure 1: The favorite programmes by the twenty seven female respondents

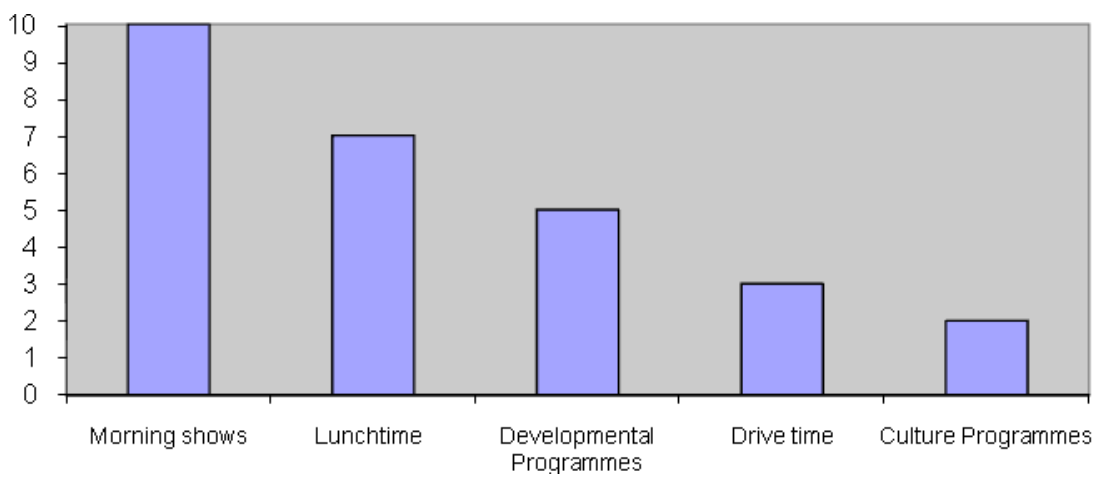

As for the favorite type of music; gospel music was cited as the most favored by nineteen respondents, music from Africa followed with six and two for music from outside Africa. Not even one respondent among females cited revolutionary music as her favorite musical genre.

The female respondents said they did not make a follow up on how often revolutionary music was played on National FM. They did not request for it either as they felt it was accorded enough time during national holidays such as Independence Day on 18 April, Heroes' Day held in August every year, and Unity Day in December celebrated every year or when a prominent ruling party hero passed on and is accorded a hero status for burial at the Heroes Acre.

The female respondents noted that the repeated playing of revolutionary music was not teaching them anything new since the type of music played was persistently repeated. They cited Simon Chimbetu's Pane Asipo (there is someone who is missing), Oliver Mtukudzi's Zimbabwe, Elliot Manyika's Nora and Cde Chinx's Vanhu vose vemuAfrica (all people in Africa) as tirelessly played to monotony during the National Holidays mentioned above. Hence they asserted that it was not necessary to play revolutionary music persistently at National FM. The respondents concluded that 'it is only appropriate to play revolutionary music at National FM during national holidays as a reminder to listeners of the importance of heroes, independence and unity for the nation's own good.'

Responding to who should select music to be played at National FM, the female respondents suggested a stakeholder operation where producer/presenters and listeners take part. The producer/presenters were chosen on the basis of their experience, exposure and access to different musical genres which they can sample and play on air for listeners to make their selections which are scored for prioritization. It is on the basis of the votes that listeners would have their favorite music chosen from the music played to them by the producer/presenters (Disk Jockeys).

Reacting, to how persistent the playing of revolutionary music on National FM had affected them, the female respondents said that it has not affected their perception in any way as revolutionary music was not played insistently on National FM except one boring Rambai makashinga (keep soldering on). Indeed this point of view by female respondents was confirmed by the researchers who assessed the Chimurenga music log sheets at National FM. We established that out of the one hundred and eighty six Chimurenga music log sheets for the month of August 2008, only twenty sheets had revolutionary songs played. Cognizant of the fact that August every year is the month during which the commemoration of Zimbabwe's heroes is held it is prudent to conclude that if revolutionary music was even more seldom played during the course of this month it means the policy on Chimurenga musical genre was dogged by resistance from stakeholders. 
Of the nine male respondents, five were indigenous businessmen and four were civil servants. From all the nine respondents, none went beyond first degree level and their ages ranged between thirty and fifty-five years.

Figure 2: Male Respondents

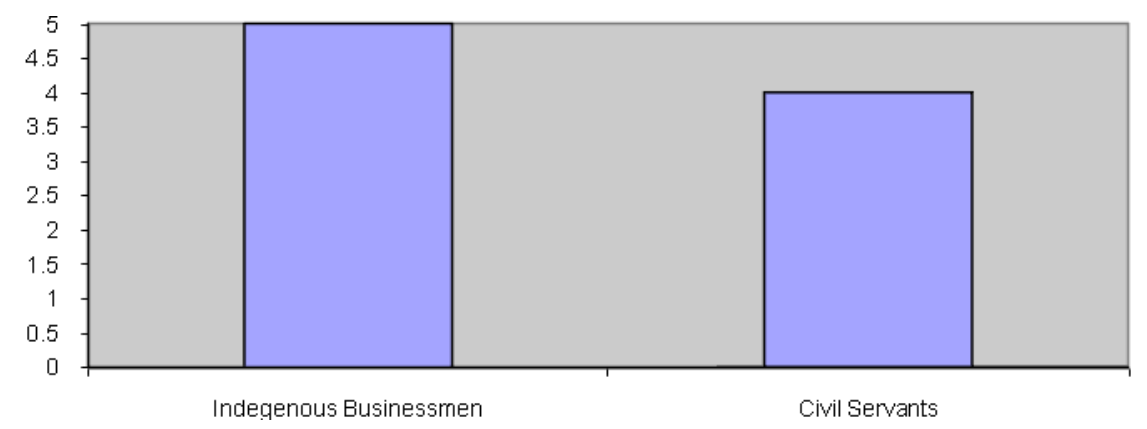

The male respondents' musical preferences were as follows; four preferred musical request, three favoured drive time and two chose morning shows. It emerged that seven respondents preferred local Sungura, one chose gospel music and one favoured music from Africa.

Answering the question on how often revolutionary music was played on National FM all nine male respondents pointed out that they did not know and even did not mind as long as the music was interesting. They however noted that they did not request for revolutionary music nor had they heard anyone request for it. They pointed out that it was critical for National FM to return to the systematic playing of other musical genres since revolutionary songs had enough time.

All male respondents recommended that the listeners determine the type of music to be played and producer/presenters contribute to a limited extent, but ZBH policy makers never take part. They asserted that they were aware that Chimurenga musical genre had its air time increased because of the need to manipulate the Zimbabwean electorate not to support opposition politics and concluded that the manipulative strategy did not affect them. They concluded that too much of something misses its objective because of the boredom or monotony it brings with it.

Two producer/ presenters from National FM were interviewed, one male and one female.

The first producer/ presenter at National FM interviewed responded as follows to the questions; I am aware of the policy. As a matter of fact, a notice has been pinned up in the transmission room for the past decade, clearly spelling out the playing of one revolutionary song out of every five songs. We all know that this is a policy issue. However, to my knowledge, no DJ has been sacked for failure to adhere to this regulation. Our bosses are always reminding us during meetings, to observe this policy. From my observation, mostly, fans are indifferent to this policy. However, not even a single fan has ever requested for revolutionary music. I think they do not have problems with the playing of music with revolutionary content here and there, especially around commemorations and anniversaries such as Heroes, Independence or Unity Day celebrations. For example if one's fans' taste is heavily biased towards the reggae genre so they request for music of this nature. The end result is that one is also influenced to have a bias towards reggae/raga music. My experience on different CD collection bears testimony to this.

The second producer/ presenter in an interview gave the following response:

The emphasis of the policy is on the playing of revolutionary music especially towards independence, heroes and Unity Day commemorations. We are required to promote the theme of the holiday thirty 
days before the anniversary. The policy took a new dimension since 2010 . When music such as the ones from The Born Free Crew, the Mahendere productions like Toita Sei? (what do we do) were played, where President Mugabe sings and one 'Siyamazi Ubaba' was broadcast either at thirty minute or one hour intervals. This was a directive from the Ministry of Information and Publicity. If one failed to comply, one was supposed to be summoned for a disciplinary hearing but up until none has been disciplined because they all complied. Only some Power FM producer/ presenters ignored this policy and were strongly reprimanded by the General Manager culminating in their sheepishly adherence to policy.

This policy was introduced around 2002 when Jonathan Moyo was Minister of Information and Publicity. The system relaxed when Jonathan Moyo was out of ZANU [PF] from 2005 to 2008. Producer/presenters played music preferred by the listeners. At the time of this research attempts were being made to enforce the policy hundred percent.

Revolutionary theme songs were largely played incessantly towards elections. Some music was banned from the air, such as Tamabaoga's 'Huwori' [Corruption], Hosea Chipanga's 'Nhunzi ne Chironda' as well as almost all of Thomas Mapfumo's music. This is despite the fact that these musicians were once popularised, favoured and given massive air play when they sang praise songs in favour of the revolutionary ZANU [PF] party.

Young musicians who play the Urban Grooves genre jumped on the bandwagon of singing songs of praise to President Robert Mugabe after realizing that it is lucrative business. The musicians were given a once off payment at production and did not receive the six dollars [\$6] paid by ZBC each time a song was played on air, through the Zimbabwe Musicians Rights Association [ZIMRA].

Responding to questions on the effectiveness of the ZBH policy of seventy five percent local and regional content, and that for every five songs played on radio, one be a revolutionary song including their effects; a trainer of journalists at the Harare Polytechnic made a number of observations. He noted that the situation could have been ideal if the national broadcaster had the resources to produce quality music, videos, dramas, sitcoms and movies so as to fill the void created by the banned or massively scaled down international broadcast products. ${ }^{50} \mathrm{He}$ added that the "policy only serves to expose how far behind we are in musical, video and film production as a nation." ${ }^{51}$ The trainer further noted that the advantage lay with satellite television providers such as SABC and BTV who reach out to the Zimbabwean market on DSTV, Wiztech, Philibao among others, consistent with the media theory of Uses and Gratifications. ${ }^{52}$ It was evident from the instructor that, the ZBH was oblivious of this phenomenon as they seemed to be doing very little to combat the Zimbabwean market's shunning of their channels. More so he noted that, if the broadcaster does not take such issues as quality production and flexibility in service provision, there is danger of the collapse of the institution. He remarked that, they cannot stop the desertion by the market except maybe if they solicit the government's aid to ban all these alternative channels and force viewers and listeners to adhere to the ZBH channels. On the contrary he warned that, compelling people to view and listen to what they do not want and value is a gross violation of the people's basic freedom of choice. With regards to the playing of Chimurenga music, the trainer said, "ZBH is making itself unpopular unnecessarily as people have alternatives in the form of compact discs. In this era of iPods, youngsters who are the target of this policy can never be ensnared as they just upload music of their choice on these gadgets. Government cannot afford to censor or control this new technology."

Trade (pseudonym), a veteran in the video and film industry employed by the University of Zimbabwe's Audio-Visual Department based at Parirenyatwa Group of Hospitals and also a trainer of journalists at the Christian College of Southern Africa [CCOSA] vigorously commented on the effects of the $\mathrm{ZBH}$ policy of seventy five percent local and regional content saying; 
Under normal circumstances, that is very ideal, although resources are a major challenge. This policy has unearthed raw talent in Zimbabwe, especially in the music industry. Talented young artists such as Rocqui, Stunner, Trevor Dongo, Sani Makhalima, to mention just a few, were unveiled to the nation as a result of the implementation of the policy which pressurized for the $75 \%$ local and regional content music to be broadcast on air. Even in the film industry, local production started with soaps such as Studio 263, Estate Blues and The Saga after the introduction of this policy and this has caught the imagination of the nation. Zimbabwe is awash with talent that needs protection as it is nurtured. If the government and the corporate world can inject loads of cash, the local music industry can actually grow to colossal proportions and create employment to the levels of Nollywood, Bollywood or even Hollywood. If we can only overcome the equipment hurdle, we have the potential to produce quality. It is only this crippling lack of funding and equipment that is militating against the industry. Otherwise even the Chimurenga musical genre that is so frequently played by ZBC can be of interest even beyond our borders if the production is quality. Look at the popularity of Thomas Mapfumo's Chimurenga music both at home and abroad. ${ }^{53}$

Remarking, on the effectiveness of the ZBH policy of playing a revolutionary song for every five played on air, Max (pseudonym), a student of Journalism and Communication at the Christian College of Southern Africa [CCOSA] noted that:

In a way it helps us to relate to the environment around us and to appreciate our own people's beliefs, culture and past. Why should we consume international music from the US, UK and elsewhere in the west when we have music locally produced, which if given extensive airplay, can receive world-wide recognition. Some people have the misconception that is a campaign gimmick by a certain political party, but Chimurenga music helps in teaching the youths of today on the history of the country and sensitize the nation as to where the country is headed towards. The music should however not be used as a tool to promote the interests of one particular political party, but should represent the interests of the nation as a whole. People should be able to embrace the message that is within the music, which in a way, should connect the youths of today to the past and the battles that were fought in order for Zimbabwe to regain independence that it enjoys today. ${ }^{54}$

\section{Discussion and conclusion}

To a large extend, the purpose of the policy of playing one revolutionary song to every five songs played on air at National FM has not been realized. It was evident from the responses of respondents that the listeners do not ardently appreciate the purpose of revolutionizing the listeners as the policy makers at ZBH purported to do by coming up with the policy of playing one revolutionary song to every five songs played at National FM. From the study of Chimurenga Music Log Sheets at National FM, it was apparent that the time allocated to the playing of revolutionary music was not being fully utilized. From the Chimurenga log sheets for the month of August 2008, only about ten percent of the total of Chimurenga music that was supposed to play on air was utilized. This could not lead to the realization of the goals of the policy. It was clear that this failure was due to the policy implementers' negative attitude towards the policy which eventually affected the listeners who did not get the maximum exposure they were expected to get according to the crafters of the policy.

Apart from the producer/ presenters' negative attitude towards the policy, the policy's intention was not realized, to a large extent, because the listeners had mild interest in the politics to do with revolutionary music. Respondents indicated that they did not request for revolutionary music because it was not part of their preferences. In addition the respondents noted that the playing of 
revolutionary music was an attempt to indoctrinate the people against a back drop of corruption, negligence, collapse of; the health delivery system, education, energy sector and water reticulation system.

Female Fan Club Members of National FM found the morning shows as their favorite programmes as presented in figure 1. The female fans preferred gospel music more than any other musical genre, followed by music from the continent. It was manifest that female National FM club members did not favour revolutionary music since there were no respondents from the sample who cited Chimurenga music as their favorite music. The female fans revealed that they love the flow of music on the station because morning shows their favorite programme was characterized by non-stop playing of a mixed genre of music usually selected by the presenter. From the foregoing it is palpable that National FM female fans are basically disinterested in music with revolutionary content.

Of the male fan club members who responded to the questionnaire, none showed enthusiasm for revolutionary music. However, the number was minimal as compared to their female counterparts so it was difficult to deduce whether the majority of male listeners did not like revolutionary music. However, of those few who responded to the questionnaire, preferred local Sungura/Museve genre to any other music. In addition they wanted the listener and the presenter to have an input into musical selection. They were indifferent to the playing of revolutionary music on National FM. They openly denounced the domineering by ZBH policy makers on the selection of musical genre. Revolutionary music was not favored even by the producer/presenters as they seldom played it despite their employer's dictated policy. Evidence to support this was obtained from the infrequency of the music's airplay drawn from the analysed Chimurenga Music Log Sheets.

The ZBH policy of playing one revolutionary song to every five songs played at National FM was ineffectual as the fans did not develop enough interest in the musical genre to such an extent that they were not affected by the music in any way. There was resistance from both the implementers and listeners. The presenters chose to play what their consumers wanted to listen to.

However, to dismiss the policy goals as totally having been unrealized would be unfair. It was elaborate that the fans were aware of the purpose of playing revolutionary music on National FM. Consequently, the impact was not as effective as the policy makers had intended it to be. The listeners were sensitive to the existence and prominence of the revolutionary musical genre which played at a time they were suffering due to economic challenges which were deepening because of the lack of commitment by the government to tackle corruption among its leaders. The music became monotonous due to its repetition by the producer/ presenters. Information collected from the $\log$ sheets showed repeated music by a few artists: Oliver Mtukudzi's Zimbabwe, Cde Chinx's Vanhu Vese Vemu Africa, Tongai Moyo's Zimbabwe, Elliot Manyika's Nora and Simon Chimbetu's Pane Asipo. The policy markers hoped that given its variety and constant air play, the musical genre could transform the mindset of the station's fans, hence making the policy effective. Overall, the respondents noted that the policy makers aimed at rekindling the support base of ZANU-PF as a political party through playing revolutionary songs regularly.

\section{Recommendations}

From the this study it is imperative for policy markers and implementers to take not of the following;

- Provide a variety of musical genre to for entertaining fans with different taste of music. 
- Stop policy imposition on the listeners instead there is need to research on the wishes and interests of the listeners and then design policies meant to capture the consumer needs.

- Allow listeners to select music played on air.

- Exclude policy makers and implementers from the music selection process.

- Research on the impact of dictated policies in general and cascade this to the music policy.

- Actively involve all stakeholders in policy formulation for both print and electronic media to acquire community buy in.

\section{Endnotes}

${ }^{1}$ Frederick S. Siebert, Wilbur Peterson and Theodore Schramm, The Four Theories of the Press, (Urbana, Illinois: University of Illinois Press, 1956), Frederick S. Siebert, Wilbur Peterson and Theodore Schramm, Four Theories of the Press: The Authoritarian, Libertarian, Social Responsibility and Soviet Communist Concepts of What the Press Should Be and Do, (Urbana: University of Illinois Press, 1963).

${ }^{2}$ Siebert F. et al., Four Theories, 3-5.

${ }^{3}$ Rivers William L., and Wilbur Schramm, "Responsibility in mass communication." (1969), accessed on 02 Feb 2011. www.getcited.org/pub/10128236227.

${ }^{4}$ Davison. S. Maruziva, "Zimbabwe" So this is Democracy? Report on the State of Media in Southern Africa, (Windhoek: MISA, 2004).

${ }^{5}$ Feltoe Geoff, A Guide to Media Law in Zimbabwe, (Harare: The Legal Resources Foundation of Zimbabwe, 2002).

${ }^{6}$ Denis McQuail, McQuail's Mass Communication Theory, (London: SAGE, 2010): 248-269.

${ }^{7}$ McQuail McQuail's Mass Communication Theory.

${ }^{8}$ West or Gale. Encyclopedia of American Law, 3rd ed. 14, (2011).

http://www.gale.cengage.com/pdf/facts/EncyclopediaAmericanLaw.pdf.

${ }^{9}$ Siebert et al, Four Theories.

${ }^{10}$ Siebert et al, The Four Theories, 3.

${ }^{11}$ Siebert et al, The Four Theories, 3.

${ }^{12}$ Denis McQuail, Mass Communication Theory: An Introduction, (London: SAGE Publications Ltd, 1987).

${ }^{13}$ McQuail, Mass Communication Theory.

${ }^{14}$ Sarah H. Chiumbu, Democracy, Human Rights Organisations and the Media: A Case Study of two Human Rights Organisations and the Media in Zimbabwe, (Blindern: University of Oslo, 1997): 94.

${ }^{15}$ Bart Cammaerts and Nico Carpentier, eds., Reclaiming the Media Communication Rights and Democratic Media Roles, (UK, Bristol: Intellect Books, 2007).

${ }^{16}$ Alot Magaga, People and communication in Kenya, (Nairobi Kenya: Kenya Literature Bureau, 1982).

${ }^{17}$ Bernard C. Cohen The Press and Foreign Policy, (Princeton, NJ: Princeton University Press, 1963).

${ }^{18}$ Nick Lewandowski, "Magic Bullet Theory in Mass Media," 1 November 2011. Accessed on 11February 2012. http://www.ehow.com/facts 5408403_magic-bullet-theory-mass-media.html.

${ }^{19}$ Maxwell. E. McCombs, and Donald L. Shaw, "The agenda setting function of mass media," Public Opinion Quarterly 36, (1972): 176-185.

${ }_{20}$ Jian Hua Zhu, and Blood Deborah, "Media Agenda-Setting Theory: Telling the Public What to Think About." In Emerging Theories of Human Communication, ed. Branslav Kovacic, (Albany, NY: SUNY Press, 1997): 88-114.

${ }^{21}$ Leon Festinger, A theory of cognitive dissonance, (Stanford, CA: Stanford University, 1957).

${ }^{22}$ Festinger, A theory of cognitive dissonance.

${ }^{23}$ Festinger, A theory of cognitive dissonance.

${ }^{24}$ Jay G. Blumler and Katz Elihu, The uses of mass communications: Current perspectives on gratifications research, (Beverly Hills, CA: Sage, 1974). 
${ }^{25}$ David Morley and Charlotte Brunsdon, The Nationwide Television Studies, (London : British Film Institute, 1978).

${ }^{26}$ B. F. Skinner, Science and Human Behavior, (New York: Macmillan, 1953).

${ }^{27}$ Katherine Miller, Communication Theories, (New York: McGraw Hill, 2005).

${ }^{28}$ Harold Gene Zucker, The Influence of Network Television News on Public Opinion, (California: University | 30 of California, 1978).

${ }^{29}$ Miller, Communication Theories.

${ }^{30}$ Zucker, The Influence of Network Television News on Public Opinion.

${ }^{31}$ Stefaan Walgrave1 and Peter Van Aelst, "The Contingency of the Mass Media's Political Agenda Setting Power: Toward a Preliminary Theory." Journal of Communication 56, (2006): 88-109.

${ }^{32}$ Gladys Engel Lang and Kurt Lang, The Battle for Public Opinion: The President, the Press and the Polls during Watergate, (New York: Columbia University Press, 1983).

${ }^{33}$ Renita Coleman and Stephen Banning, "Network TV news' affective framing of the presidential candidates: evidence of second-level agenda-setting effect through visual framing," Journalism and Mass Communication Quarterly 83, no. 2 (2006): 313-328.

${ }^{34}$ Kurt Lewin, "Frontiers in group dynamics II: Channels of group life; social planning and action research," Human Relations 1, (1947): 143-153.

${ }^{35}$ Norton E. Long, "The local community as an ecology of games." American Journal of Sociology 64 (November), (1958): 251-261.

${ }^{36}$ Werner J. Severin and James W. Tankard, Communication Theories, (London: Longman, 1988).

${ }^{37}$ Katherine Miller, Communication Theories: Perspectives, processes and contexts, $2^{\text {nd }}$ ed. (Boston, MA: McGraw-Hill, 2009).

${ }^{38}$ Dietram A. Scheufele, "Framing as a Theory of Media Effects," Journal of Contemporary Communication 49, no. 1 (1999): 103-122.

${ }^{39}$ Peter Burke, History and Social Theory, (Cambridge: Polity Press, 2005).

40 Antonio Gramsci, Selections from the Prison Notebooks of Antonio Gramsci, (New York: International Publishers, 1971).

${ }^{41}$ Dick Hebdige, "From Culture to Hegemony." In The cultural Studies reader, ed. Simon During, (London: Routledge, 1994): 365.

${ }^{42}$ Denis McQuail, McQuail's Mass Communication Theory. $5^{\text {th }}$ ed. (London: Sage, 2005).

${ }^{43}$ Nick Stevenson, Understanding Media Cultures: Social Theory and Mass Communication, (London: Sage, 1995).

${ }^{44}$ Burke, History and Social Theory.

${ }^{45}$ Louis Althusser, "Ideology and Ideological State Apparatus." In Lenin and Philosophy and Other Essays, ed. Louis. Althusser, (New York City: Monthly Review Press, 1971): 127-186.

${ }^{46}$ Hebdige, Dick. From Culture, 365.

${ }^{47}$ Tankard et al: 1991.

${ }^{48}$ John B. Thompson, Ideology and Modern Culture: Critical Social Theory in the Era of Mass Communication, (Cambridge: University of Cambridge and Fellow of Jesus College, 1990).

${ }^{49}$ Burke, History and Social Theory.

${ }^{50}$ Makes (pseudo name), (approximately 34 years), Interview, a lecturer of Electronic Media Studies in the Mass Communications Department at the Harare Polytechnic, at the Harare Polytechnic College on 15 October 2011.

${ }^{51}$ Makes (pseudo name). Interview.

${ }_{52}^{52}$ Makes (pseudo name). Interview.

53 Trade (33 years), Interview, film editor with the University of Zimbabwe's Audio Visual services, also Trainer of Film and Video-graphy at the Christian College of Southern Africa, at the University Zimbabwe Studios at Parirenyatwa Group of Hospitals on 12 November 2011.

${ }^{54}$ Max (23 years), Interview, a student of Journalism on Internship at Zimpapers, at the Zimpapers Newsroom on 10 February 2012. 